\title{
Effect of Soil Solarization on Soil Borne Fungi, the Growth and Yield of Tomato Grown In Clay Loam Soil at Alexandria Governorate, Egypt
}

\author{
Yakout, T.R. ${ }^{1}$, Manal, M.S. Zen-El-Dein ${ }^{2}$
}

\begin{abstract}
Mulching by $100 \mu$ thickness transparent plastic sheets compared with specific fungicides for controlling soil borne fungi were carried out at Al-Sabahia, Horticulture Research Station, Alexandria Governorate, Egypt. Solar heating resulted from mulching gradually reduced the tested soil borne-fungi to very low levels, comparable with non-mulched treatment. Soil Temperature, fungal frequency and tomato yield were recorded during the experimental seasons. The results indicated that there were no significant differences between the three months mulching and specific fungicides treatments effect against soil borne fungi. So, it could be concluded that possibility of using mulching method to control soil-borne diseases pathogens in the clay loam soil by planting the crop in solarized fields.

The results also proved significant effect of the soil solarization on the vegetative growth of tomato plants and enhanced the yield and its components compared with the control. The results for the total yield per feddan proved that there were no significant differences between the treated root with fungicide and the three month soil solarization treatments in both seasons. The percentages increase in the estimated total yield per feddan were 21.40, $18.95,12.40$ and $3.11 \%$ for treated root with fungicide, three, two and one month treatments over the control, respectively in 2014 season, whereas, they were 25.65 , $22.51,16.40$ and $9.52 \%$ for the same treatments, respectively in the 2015 season.
\end{abstract}

Key words: Solarization - Mulch - Soil Borne Fungi Tomato

\section{INTRODUCTION}

Egypt produses tomato (Lycopersicon esculenturn Mill) all over the year where it is one of the most important economic Solanaceous vegetable crops for local consumption and exportation. The problem is that tomatoes subjected for attacking by many diseases wherever the crop is planted. Damping off and wilt agents caused by soil borne fungi pathogen causing a considerable reduction of its production. The wilt disease caused by Fusariurn oxysporum fsp. lycopersici (Sace.), and Rhizoctonia solani Kuhn have serious effects on tomato plants either in nurseries or in the fields, (Besri, 1982).

\footnotetext{
${ }^{1}$. Protected Cultivation Res. Dept., Horticultural Research Institute, ARC, Giza, Egypt

${ }^{2}$ Central Agricultural Pesticides Laboratory; Research Center, Alexandria, Egypt.

Received December 18, 2016, Accepted December 29, 2016
}

Soil solarization is a non-chemical soil treatment that utilizes solar radiation and a thin film of transparent mulch, usually of polyethylene, to heat the soil to a range of 38 to $50^{\circ} \mathrm{C}$ to a depth of about 10 to $20 \mathrm{~cm}$ (Gamliel and Katan, 2012) for soil pasteurization. It is also a method for controlling, mesophilic organisms, which include most plant pathogens (such as soil borne fungi) and other pests, without destroying the beneficial bacteria and mycorrhizal fungi (Pullman et al., 1981; Stapleton and DeVay, 1984, 1986; Stapleton, 1991 and Minuto et al., 1995). It is a hydrothermal process for controlling soil harm pests and it is widely used nowadays to eliminate soil-borne disease incidence, (McGovern et al., 2000). Promising results for controlling soil-borne pests in regions having high temperature and intense solar radiation could be obtained by applying soil solarization, (Polizzi et al., 2003 and Rodriguez et al., 2004). Soil solarization also offers a new tool for weed management and is a viable weed management strategy for organic farmers, (Marquez and Wang, 2014).

Solar radiation with short wavelengths (about 120 - 400 nanometers) carries higher amounts of energy than does radiation with longer wavelengths (infrared radiation). The transparent plastic tarp used in solarization transmits ultraviolet (UV) and visible light but not infrared radiation (IR) known as photoselective polyethylene (PE) plastic (Chellemi, 2006). As the short-wavelength solar radiation passes through the plastic layer, it loses energy; the wavelengths increase in length and the radiation essentially becomes infrared radiation that generates heat. This heat is trapped beneath the plastic where it warms the soil (Krueger and McSorley, 2009). The second mechanism of soil solarization is through a solar heating process by soil moisture. Soil moisture conducts heat, evaporates and increases the maximum soil temperature (Mahrer and Shilo, 2012). Water has the property to be a good absorber of infrared and ultraviolet radiation. This is because water has a high specific heat capacity (capacity to absorb heat) allowing it to contain a great amount of thermal energy. 
Chemical treatments may be dangerous to environment and soil microbial processes, where it affects beneficial and non-beneficial organisms in soil. Ahmed et al., (2002) found that Dazomet, as a preplanting soil fumigant, had detrimental effects on the different stages of both the Mediterranean fruit fly; Ceratitis capitata (Wied.) and the cotton leafworm; Spodoptera littoralis (Boisd.) in two different soil types. And so, Mansoori and Jaliani (1996) and El-Shahaat et al., (2005) found that Basamid (dazomet) ${ }^{\circledR}$ as soil fumigant had an appreciable decreasing effect on three species of terrestrial snails, pre-pupal stages of both the cotton leafworm and the Mediterreanan fruit fly in a sand loam soil and appeared to decrease the $\mathrm{NO}_{2}-\mathrm{N}$ formation when incorporated into soil. Also, this compound highly inhibited dehydrogenase enzyme activity in soil.

Egypt possesses factors needed for successful soil solarization (mulching), which was introduced as an important technology to minimize the harmful effects of soil-borne diseases in the traditional agriculture in Egypt in 1981 (Satour, 1997). Katan, (1985) and Satour et al., (1991) stated that soil solarization is a very effective treatment against several borne diseases that infect onion, tomato and sorghum, besides, several nematodes and most of the common weed species could also be completely controlled Stapleton, (2008).

Advantages of Mulching, (Dalorima et al., 2014); 1) It prevents the direct evaporations of moisture from the soil and thus limits the water losses and conserves moisture. 2) Mulch can facilitate fertilizer placement and reduce the loss of plant nutrient through hatching. 3) Mulching can provide a barrier to soil pathogens. On strawperry, Soliman et al., (2015) tested three strawberry cultivars under mulched with clear or black polyethylene. They concluded that significant increases in number of leaves, number of crown, leaf area, dry mass/plant, number of flower trusses/plant and it flowered earlier than the non-mulched.

The present study was carried out to evaluate the importance of using a physical soil solarization method against soil-borne fungi responsible for damping off diseases of tomato plants in Egypt comparing with standard fungicide.

\section{MATERIALS AND METHODS}

The current study was conducted in two successive growing seasons, (2014 and 2015) in Clay loam soil at Al-Sabahia, Horticulture Research Station, Alexandria Governorate, Egypt. The experimental field was naturally highly infested with soil-borne pathogens (such as Fusariurn oxisporium, Penicillium spp., and Rhizoctonia solani). Tomato (Lycopersicon esculenturn Mill) cv. Castle Rock seeds obtained from private nursery were used for the current study. The tomato seeds were sown in nursery in the $1^{\text {st }}$ week of July in both seasons and seedlings were transplanted in the experimental field in the $2^{\text {nd }}$ week of August in both seasons. Individual plots of $3 \times 6 \mathrm{~m}$ were arranged in a complete randomized block design (CRBD) with four replications. The distance between rows was $1.50 \mathrm{~m}$ whereas the distance between plants within the row was $50 \mathrm{~cm}$. Plots were ploughed, leveled and surface irrigated, divided into 4 blocks (divided to plots $3 \times 6 \mathrm{~m}$ as replicates) covered with a transparent PE (100 $\mu \mathrm{m}$ thickness) plastic sheets for one, two and three months intervals for soil solarization before transplanting the seedling. Plants were irrigated by drip irrigation lines under the mulch. Water and fertilizers were applied through the irrigation lines. The most common recommended agronomic practices for tomato were followed throughout this investigation as recommended by the Ministry of Agriculture.

The experimental treatments were as follow:

1- Treated Roots with fungicide in non-mulched plots (Tr-root).

2- Untreated roots in plots covered with transparent plastic sheets for 3 months, (Mul3m).

3- Untreated roots in plots covered with transparent plastic sheets for 2 months, (Mul2m).

4- Untreated roots in plots covered with transparent plastic sheets for 1 month, (Mul1m).

5- Untreated roots in non-mulched (control) plots (UnMul).

\section{Measurements:}

\section{Environmental measurements:}

Two tensiometers placed at $10 \mathrm{~cm}$ depth within plant rows for monitoring the soil moisture. Soil temperature was measured throughout the plant growth period using mercury-in-glass geothermometers in one plot of each mulching treatment. Geo-thermometers were buried at 10 $\mathrm{cm}$ depths in the mulched plots within the rows of tomato plants. Daily measurements of soil temperature were taken at 9:00 am and every 2 hours along the day, local standard time (LST), (Schneider, 1979).

\section{Vegetative measurements}

Tomatoes yield were recorded at harvest times for every replicate of treatments to calculate the yield/Feddan comparing with control treatment. Random samples of five plants from each replicate were taken after 120 days from transplanting to record the following characters:- 


\subsection{Vegetative growth characteristics}

2.1.1. Plant height $(\mathrm{cm})$.

2.1.2. Number of branches per plant.

2.1.3. Number of leaves per plant.

2.1.4. Plant dry matter percentage.

2.1.5. Stem diameter

\subsection{Fruit physical characteristics:-}

2.2.1. Fruit length $(\mathrm{cm})$

2.2.2. fruit diameter $(\mathrm{cm})$.

2.3. Yield and its components:-

2.3.1. Number of fruit per plant

2.3.2. Average fruit weight (g).

2.3.3. Total yield (kg\plant).

2.3.4. Total yield (ton $\backslash$ fadden).

\section{Fungal count:}

Soil samples $(0-15 \mathrm{~cm})$ were taken [for counting fungal (cfu)] from the experimental plots of each treatment (at about $15 \mathrm{~cm}$ depth around plants roots) at the end of each solarization period (1, 2 and 3 months). Composite samples and three sub-samples from each plot were used for determining the fungal populations according to the method of Grossman (1967). Fungal frequency was recorded in 4 replicate plates after incubation for 7 days at $30{ }^{\circ} \mathrm{C}$ and the most frequent fungi in the non-covered soil were tested for their tolerance to solarization (Zen El-Dein, and Yakout, 2013).

\subsection{Tested fungicide:}

Propamocarb hydrochloride-Fos-tyl-Aluminium (Seedlings treatment) produced by Bayer Corp Science which called Previcur energy $84 \%{ }^{\circledR}$ in the formula SL was applied by the rate of $3.0 \mathrm{~cm} / 1$ litter water. Experimental plots were observed daily after transplanting for slanted and dead plants by soil borne pathogens only.

\section{Statistical Analysis:}

The experimental design was a complete random block design with four replicates. The analysis of variance was used to analyze the obtained data as outlined by Snedecor and Cochran (1994). Comparisons among the means of different treatments were done, using least significant difference test procedure at $\mathrm{P}=$ 0.05 level of significance using CoStat Ver. 6.311 Software package (2005).

\section{RESULTS AND DISCUSSION}

\section{Soil temperatures:}

As shown in Figs. (1 and 2) differences in the soil temperatures between the mulched and un-mulched soils were observed. During $1^{\text {st }}$ season, averages temperature for the un-mulched soil were 23.6, 25.4 and $19.4{ }^{\circ} \mathrm{C}$ for the $1^{\text {st }}, 2^{\text {nd }}$ and $3^{\text {rd }}$ months, respectively whereas, they were $34.2,35.2$ and 24.3 ${ }^{\circ} \mathrm{C}$ during the same months, respectively for the mulched soil by transparent plastic sheet. The percentages increases in the mulched soil temperatures over the un-mulched were 44.92, 38.58 and $25.26 \%$, respectively for the same months. Whereas in the $2^{\text {nd }}$ season the averages temperatures for the un-mulched soils were $24.8,22.1$ and $20.3^{\circ} \mathrm{C}$ during $1^{\text {st }}, 2^{\text {nd }}$ and $3^{\text {rd }}$ months, respectively whereas, they were $36.7,31.6$ and $26.1{ }^{\circ} \mathrm{C}$ during the same months, respectively for the mulched soil by transparent plastic sheet. The percentages increases in the mulched soil temperature over the un-mulched one were $47.98,42.99$ and $28.57 \%$, respectively for the same months. Close results were obtained by Salman et al., (1991) since polyethylene mulch had lower soil temperature in the late of season where the vegetative growth covered the soil surface and the effect of mulch on soil temperature was reduced. It could be concluded from the present results that mulching (soil solarization) caused increasing of soil temperature throughout $15 \mathrm{~cm}$ depth. Many investigators reported the positive effect of soil solarization on increasing soil temperature, (Hillel et al., 1982; Sarhan, 1991 and Satour, 1997). Clear polyethylene on the other hand caused increases of temperature as much as 8 ${ }^{\circ} \mathrm{C}$. According to Mashingaidze and Chivinge (1998) clear or translucent plastic was generally the best for solarization. Depending on soil depth, maximum temperatures of solarized soil in the field are commonly between $42^{\circ} \mathrm{C}$ to $55^{\circ} \mathrm{C}$ at the upper $2.5 \mathrm{~cm}$ depth and range from $32^{\circ} \mathrm{C}$ to $36^{\circ} \mathrm{C}$ at greater depths (DeVay, 1991).

\section{Fungal count:}

From the zero time data, it is clear that Rhizoctonia solani fungi seems to be had the most mean population density $\left(10^{3} \mathrm{cfu} / \mathrm{g}\right)$ in the experimental area followed by Aspergillus niger fungi, where Fusarium oxisporium had the least mean population density, during the two growing seasons.

Table (1) showed that there were significant differences between the effects of the mulching period of one, two and three months. Also, there were significant differences between the effect of mulching control method and chemical control method. The data that the tested fungi affected by the different treatments showed can be arranged in the following order: Fusarium oxisporium, Rhizoctonia solani and Aspergillus niger with significant differences among them. 


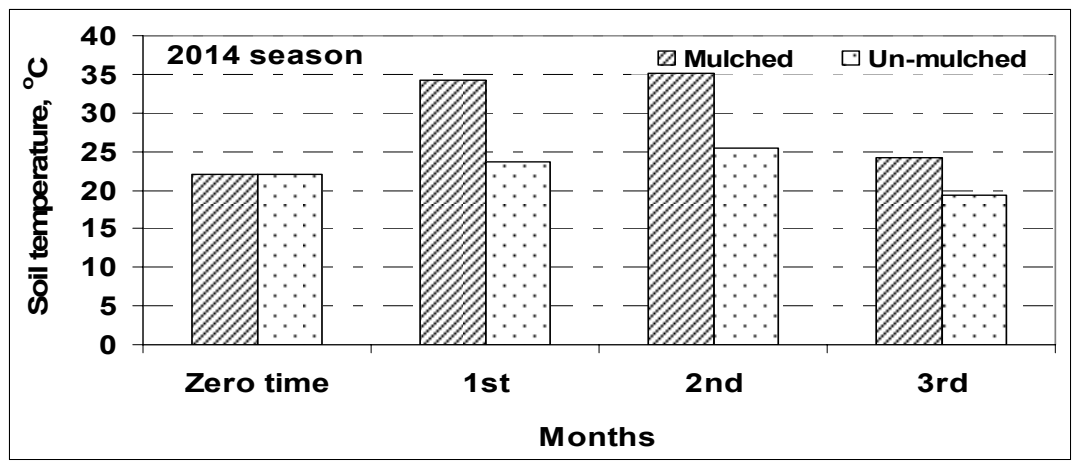

Fig. 1. Soil temperatures in the 2014 season for mulched and un-mulched soil for the $1^{\text {st }}, 2^{\text {nd }}$ and $3^{\text {rd }}$ months

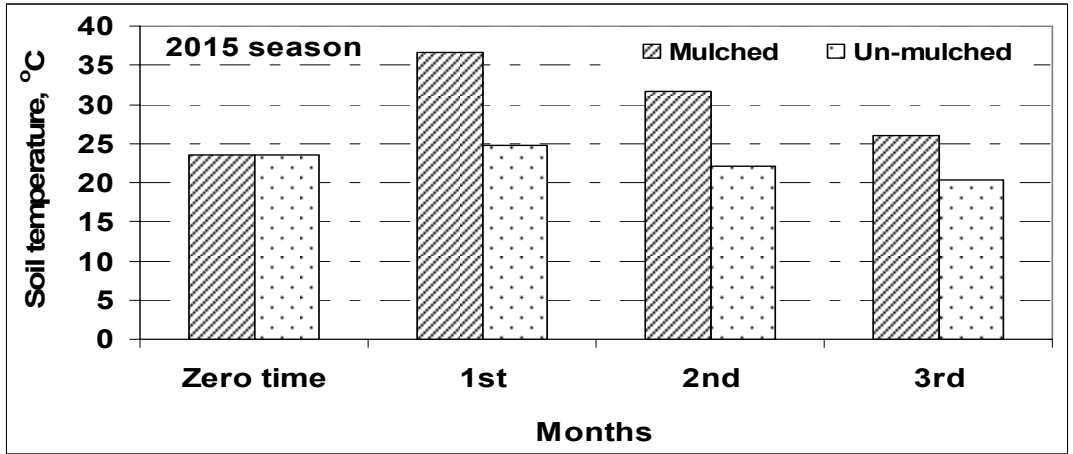

Fig. 2. Soil temperatures in the 2015 season for mulched and un-mulched soil for the $\mathbf{1}^{\text {st }}, 2^{\text {nd }}$ and $3^{\text {rd }}$ months

Table 1. Comparing the effect of chemical control (Previcur energy 84\%) and non-chemical (mulching) treatments against soil borne fungi population density $\left(10^{3} \mathrm{cfu} / \mathrm{g}\right)$ during 2014 season

\begin{tabular}{|c|c|c|c|c|}
\hline \multirow{2}{*}{ Fungi } & \multirow{2}{*}{ Time (month) } & Transparent & Control & Previcur energy 84\% \\
\hline & & \multicolumn{3}{|c|}{ Fungal frequency } \\
\hline \multirow{4}{*}{ Aspergillus niger } & 0 & & 47.64 & \\
\hline & 1 & 27.27 & 46.35 & 31.29 \\
\hline & 2 & 26.83 & 40.72 & 32.79 \\
\hline & 3 & 19.01 & 45.17 & 28.37 \\
\hline \multirow{4}{*}{ Rhizoctonia solani } & 0 & & 44.82 & \\
\hline & 1 & 11.67 & 46.53 & 12.96 \\
\hline & 2 & 6.85 & 54.57 & 28.08 \\
\hline & 3 & 0.47 & 71.00 & 34.15 \\
\hline \multirow{4}{*}{ Fusarium oxisporium } & 0 & & 27.40 & \\
\hline & 1 & 3.37 & 18.81 & 5.03 \\
\hline & 2 & 3.94 & 16.85 & 6.10 \\
\hline & 3 & 3.79 & 26.75 & 5.35 \\
\hline \multirow{3}{*}{ L.S.D 0.05} & Time & & 1.367 & \\
\hline & Treatments & & 2.087 & \\
\hline & Fungus & & 2.126 & \\
\hline
\end{tabular}

$\mathrm{cfu} / \mathrm{g}=$ count of fungal colony forming units per gram of soil weight. 
Table 2. Comparing the effect of chemical control (Previcur energy 84\%) and non-chemical (mulching) treatments against soil borne fungi population density $\left(10^{3} \mathrm{cfu} / \mathrm{g}\right)$ during 2015 season

\begin{tabular}{|c|c|c|c|c|}
\hline \multirow{2}{*}{ Fungi } & \multirow{2}{*}{ Time (month) } & Transparent & Control & Previcur energy $84 \%$ \\
\hline & & \multicolumn{3}{|c|}{ Fungal frequency } \\
\hline \multirow{4}{*}{ Aspergillus niger } & 0 & \multicolumn{3}{|c|}{65.2} \\
\hline & 1 & 32.73 & 55.62 & 37.55 \\
\hline & 2 & 29.51 & 56.49 & 36.07 \\
\hline & 3 & 17.10 & 67.55 & 25.53 \\
\hline \multirow{4}{*}{ Rhizoctonia solani } & 0 & \multicolumn{3}{|c|}{52.6} \\
\hline & 1 & 15.18 & 53.61 & 36.85 \\
\hline & 2 & 8.22 & 63.74 & 21.81 \\
\hline & 3 & 0.45 & 47.44 & 23.70 \\
\hline \multirow{4}{*}{ Fusarium oxisporium } & 0 & \multicolumn{3}{|c|}{25.7} \\
\hline & 1 & 14.05 & 22.58 & 16.03 \\
\hline & 2 & 5.12 & 21.90 & 8.65 \\
\hline & 3 & 7.58 & 23.51 & 10.70 \\
\hline \multirow{3}{*}{ L.S. $D_{0.05}$} & Time & \multicolumn{3}{|c|}{2.117} \\
\hline & \multirow{2}{*}{\multicolumn{2}{|c|}{ Treatments }} & \multicolumn{2}{|l|}{2.519} \\
\hline & & & \multicolumn{2}{|l|}{2.436} \\
\hline
\end{tabular}

$\mathrm{cfu} / \mathrm{g}=$ count of fungal colony forming units per gram of soil weight.

The recorded results of the $2^{\text {nd }}$ season of the experiment (Table, 2) showed the same trend of the first season. Mulching by transparent sheets decreased the population density of Aspergillus niger from 32.73 to $17.10 \mathrm{cfu} / \mathrm{g}$, Rhizoctonia solani from 15.18 to 0.45 cfu/g, and Fusarium oxisporium from 14.05 to 7.58 $\mathrm{cfu} / \mathrm{g}$. Treating roots with specific fungicide (Previcur energy $84 \%{ }^{\circledR}$ ) decreased the population density of $A$. niger (from 37.55 to $25.53 \mathrm{cfu} / \mathrm{g}$ ), $R$. solani (from 36.85 to 23.70), and $F$. oxisporium (from 16.03 to 10.70). Untreated blocks indicated that population density (cfu/g) of all tested soil borne fungi increased during the experimental period.

These results confirm those obtained by Katan \& DeVay (1991) and Pullman and DeVay (1984). They stated that the efficiency of solarization would be improved by increasing the mulching time. Standifer et al., (1984); Abou-Gharbieh et al., (1991); Morgan et al., (1991); Moura and Palminha (1994); Stapleton, (2000) and Minuto et al., (2006) also reported that the effect of transparent sheet on the microorganisms was, generally higher than of the black one.

The observations indicated that there were no weeds grown in the solarized plots. This result is in agreement with that reported by Dabaj et al., (2005) who mentioned that soil solarization with plastic sheets was effective against soil inhabiting pests and pathogens, especially root knot nematode; Meloidogyne spp. and annual and perennial weeds. Also, Bawazir and Aidaros (2005) used transparent and black polyethylene sheets mulching for 30 or 60 days in Delta Tuban, Yemen. They found that soil solarization decreased significantly the annual weed population in the field. Mulching with transparent sheets for 30 or 60 days was better than that with black sheets.

A successful work of soil solarization will basically reduce the majority types of soil-borne plant pathogens and weed seeds from the top 5 to $7.5 \mathrm{~cm}$ of soil with decrease of these pests at larger depths (McSorley and Gill, 2013).

\section{Vegetative characters:}

\subsection{Vegetative growth:}

The vegetative growth results of tomato plants are shown in Table (3).

\subsubsection{Plant height (cm)}

Table (3) illustrated a highly significant effect of the soil solarization on plant height. All treatments increased the height of tomato plant than the control except for the mulched soil for one month. The results also indicated that there was no significant difference between the treated root with fungicide and the mulched soil for three months. The data also showed that the mulched soil for two or one month did not significantly differ than the un-mulched soil in this trait, in 2014 season.

In 2015 season, the data also, showed that the plants of solarized soil acquired significant increase in plant height. The results showed significant increase in plant height for treated root with fungicide than the solarized soil treatments. The data also, indicated that there was no significant difference between the two or three months soil solarization treatments.

Close results were found by Salman et al., (1991) who noted that the effect of mulching on plant height and leaf number of cucumber plant indicated that the 
lowest plant height and leaf number occurred in unmulched soil. Also, Dalorima, et al., (2014) who found that growth parameter like plant height had no significant difference between plastic mulch, sorghum straw mulch, sawdust mulch and the control treatments but all treatments have some superiority to the control.

\subsubsection{Number of branches per plant}

In 2014 season, significant effect was attained by different soil mulching treatments in the number of leaves per plants. All treatments increased the number of branches per plant of tomato plant than the control except for the mulched soil for one month. The results also, indicated that there was no significant difference between the treated root with fungicide and the mulched soil for three months. The data also showed that the mulched soil for two months significantly differed than the one month mulched soil and the un-mulched one.

In 2015 season, all treatments showed significant increase in the number of branches per plant than the un-mulched soil plants. The results also, indicated that all treatments were significantly differed.

These results were in agreement with Rajablariani et al., (2012) who found that the number of branches per plant were better for the plants grown under plastic mulch compared with bare soil.

\subsubsection{Number of leaves/plant}

In 2014 season, Table (3) cleared out a highly significant effect of the soil solarization on number of leaves per plant. All treatments increased the number of leaves per plant of tomato than the control one except for the mulched soil for one month. The results also indicated that there was no significant difference between the treated root with fungicide and the mulched soil for three months. The data also showed that either the mulched soil for two or one month did not significantly differ than the un-mulched soil in this trait.

In 2015 season, Table (3) demonstrated that there was significant difference between the treated roots with fungicide and the three months solarized soil plants. The data also showed that there was significant difference between the two months solarized soil and one month treatments.

Very close results were obtained by Rajablariani et al., (2012), who noted that number of leaves per plant was better for the plants grown under plastic mulch compared to bare soil.

\subsubsection{Dry matter percentage}

In 2014, Table (3) also showed a significant different of the soil mulch in the dry matter percentage of plant. There was a significant difference between the treated roots with fungicide and the mulched soil for three months. Whereas, the data showed that there was no significant difference between the mulched soil for three or two months. Also, the results pointed out that there was no significant difference between the mulched soil for one month and the un-mulched soil concerning the dry matter percentage.

In 2015 season, all treatments showed significant increase in the dry matter percentage of plants than the un-mulched soil plants. The results also, indicated that all treatments were significantly differed. Keeping the plastic in place for at least six weeks to accomplish its effect on resisting soil fungi was recommended by McSorley and Gill. (2013).

\subsubsection{Stem diameter $(\mathrm{cm})$}

Table (3) illustrated a highly significant effect of soil solarization on stem diameter. All treatments increased the stem diameter of tomato plants than the un-mulched one. The results also demonstrated that there was no significant difference between the treated root with fungicide and the mulched soil for three months. The data also showed that either the mulched soil for two or one month did not significantly differ than the un-mulched soil in this trait.

Table 3. Effect of different treatments on the vegetative growth of tomato plant in the two growth seasons

\begin{tabular}{|c|c|c|c|c|c|c|c|c|c|c|}
\hline Treat* & $\begin{array}{c}\text { Plant } \\
\text { height } \\
\text { (cm) }\end{array}$ & $\begin{array}{c}\text { No of } \\
\text { branches } \\
\text { /plant }\end{array}$ & $\begin{array}{c}\text { No } \\
\text { leaves } \\
\text { /plant }\end{array}$ & $\begin{array}{c}\text { Dry } \\
\text { matter } \\
(\%)\end{array}$ & $\begin{array}{c}\text { Stem } \\
\text { diam. } \\
(\mathrm{cm})\end{array}$ & $\begin{array}{c}\text { Plant } \\
\text { height } \\
\text { (cm) }\end{array}$ & $\begin{array}{c}\text { No of } \\
\text { branches } \\
\text { /plant }\end{array}$ & $\begin{array}{c}\text { No } \\
\text { leaves } \\
\text { /plant }\end{array}$ & $\begin{array}{c}\text { Dry } \\
\text { matter } \\
(\%)\end{array}$ & $\begin{array}{r}\text { Stem } \\
\text { diam. } \\
(\mathrm{cm})\end{array}$ \\
\hline & \multicolumn{5}{|c|}{2014 season } & \multicolumn{5}{|c|}{2015 season } \\
\hline Tr-root & $81.5 \mathrm{a}$ & $6.98 \mathrm{a}$ & $108.1 \mathrm{a}$ & $20.33 \mathrm{a}$ & $1.35 \mathrm{a}$ & $87.6 \mathrm{a}$ & $7.43 \mathrm{a}$ & $115.0 \mathrm{a}$ & $21.86 \mathrm{a}$ & $1.43 \mathrm{a}$ \\
\hline Mul3m & $78.7 \mathrm{a}$ & $6.77 \mathrm{a}$ & $98.4 \mathrm{a}$ & $19.19 b$ & $1.22 \mathrm{a}$ & $81.2 b$ & $7.13 b$ & $102.5 b$ & $20.41 b$ & $1.30 \mathrm{a}$ \\
\hline $\operatorname{Mul2m}$ & $72.8 b$ & $6.06 b$ & $84.3 b$ & $18.30 \mathrm{~b}$ & $0.81 b$ & $77.5 b$ & $6.45 c$ & $88.8 \mathrm{c}$ & $19.06 \mathrm{c}$ & $0.90 b$ \\
\hline Mullm & $67.5 b$ & $5.38 \mathrm{c}$ & $75.4 \mathrm{~b}$ & $15.94 \mathrm{c}$ & $0.76 b$ & $68.7 \mathrm{c}$ & $5.85 \mathrm{~d}$ & $82.0 \mathrm{~cd}$ & $17.33 d$ & $0.83 b$ \\
\hline UnMul & $69.9 b$ & $5.43 c$ & $82.0 \mathrm{~b}$ & $16.47 \mathrm{c}$ & $0.69 b$ & $53.8 \mathrm{~d}$ & $5.13 \mathrm{e}$ & $76.3 \mathrm{~d}$ & $15.65 \mathrm{e}$ & $0.73 b$ \\
\hline LSD0.05 & 5.2 & 0.28 & 10.4 & 0.90 & 0.18 & 5.84 & 0.09 & 11.69 & 1.04 & 0.19 \\
\hline
\end{tabular}

*Tr-root $=$ treated roots $\quad$ Mul3m= mulched for 3 months $\quad$ Mul2m= mulched for 2 months $\quad$ Mul1m= mulched 1

month UnMul= Un-mulched

The means with the same latter are not significantly differ. 
Close results were found by Abu-Bakr and El-Balla (2003), who stated that plastic mulch significantly increased seedling emergence and improved plant growth of okra,

\subsection{Yield and its components:}

The impact of soil solarization on yield and its components is shown in Table (4).

\subsubsection{Fruit length (cm)}

Table (4) illustrated a highly response of plant fruit length to the soil solarization throughout the two growing seasons. The data of fruit length showed that the treated root and the solarized soil for three months were significant in the second season only. There were significant differences between the other soil solarization treatments and the control in both seasons.

\subsubsection{Fruit diameter $(\mathrm{cm})$}

Table (4) showed that the average fruit diameter was affected by different solarization treatments. The data also indicated that the plants of treated root and three months soil solarization treatments were not significantly differ.

\subsubsection{Number of fruit per plant}

Table (4) indicated that there were no significant differences between all treatments in both seasons.

\subsubsection{Average fruit weight (g)}

Table (4) illustrated that all soil solarization treatments increased the average fruit weight. The data also proved that there were no significant differences between the treated root with fungicide and the three month soil solarization treatments in both seasons. The results also indicated that there were no significant differences between the one month soil solarization treatment and the control in both seasons.

Plants often grow faster and produce both higher and better-quality yields when grown in solarized soil. This can be attributed, in part, to improved disease and weed control. A number of factors may be involved; i) minor or unknown pests may also be controlled, ii) the increase in soluble nutrients improves plant growth, iii) relatively greater populations of helpful soil microorganisms have been documented following solarization, and some of these, such as certain fluorescent pseudomonad and Bacillus bacteria, are known to be biological control agents (Elmore et al., 1997).

\subsubsection{Total yield per plant $(\mathrm{kg})$}

All soil solarization treatments increased the total yield of tomato per plant than the control treatment, (Table, 4). The highest total yield per plant was obtained by the treated root with fungicide treatment followed by the three months soil solarization treatment in both seasons. The data also cleared that there were no significant differences between the treated root with fungicide and the three month soil solarization treatments in both seasons. The results also, indicated that there were no significant differences between the one month soil solarization treatment and the control in both seasons.

Increased yield has been largely attributed to increase in soil temperature due to application of mulching, (Salman et al., 1991). Solarization with clear mulches increased lettuce yield by enhancing plant growth and head weight, (Hasing, 2002). Plastic mulches significantly increased total yield of okra, (Abu-Bakr and El-Balla, 2003).

\subsubsection{Total yield per feddan (ton)}

The estimated total yield of tomato per feddan showed a significant increase with all treatments than the control, (Table, 4). The highest total yield per feddan was obtained by the treated root with fungicide treatment followed by the three months soil solarization treatment in both seasons. The data also cleared that there were no significant differences between the treated root with fungicide and the three month soil solarization treatments in both seasons. The results also, pointed out that there were no significant differences between the one month soil solarization treatment and the control in both seasons. The percentages increases in total yield per feddan were 21.40, 18.95, 12.40 and $3.11 \%$ for treated root with fungicide, three, two and one month treatments over the control, respectively in 2014 season whereas, they were $25.65,22.51,16.40$ and $9.52 \%$ for the same treatments, respectively in the 2015 season.

Very close results were reported by other authors; Total yield was slightly higher by using black mulch than by clear mulch, but both of them have significantly increased the total yield as compared with un-mulched soil treatments, (Salman et al., 1991). The clear plastic mulches increased total yield by $46.0 \%$ compared to the control (Abu-Bakr and El-Balla 2003). Mulching increased marketable yield relative to bare soil as the plants grown on plastic mulch indicated $65 \%$ increasing in marketable yield compared to control treatment (Rajablariani et al., 2012). When soil was subjected to solarization for only four to five weeks using two layers of clear plastic separated by a 1-inch gap, the yield of fall snap beans harvested two months after solarization was increased by over 90 percent, (McSorley and Gill. 2013). 


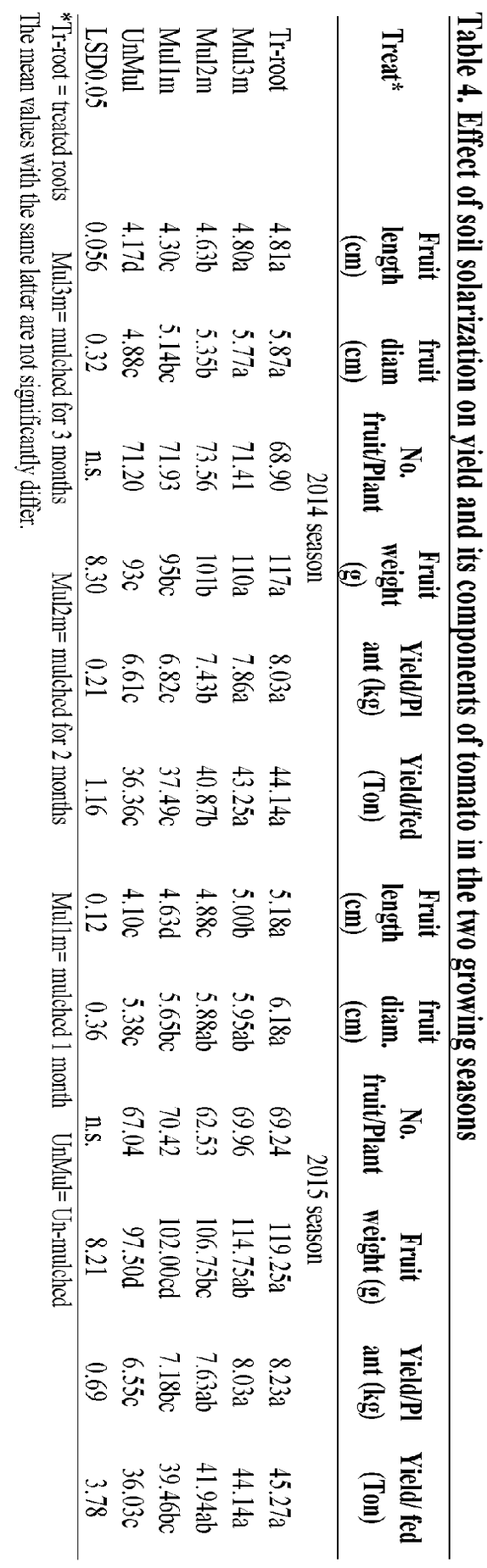


On strawperry, Soliman et al., (2015) who found that early yield, total yield, yield/plant, marketable yield, culls yield and average fruit weight were positively and significantly increased by the application of mulch (clear and black polyethylene mulch) compared to nonmulched.

\section{CONCLUSION}

The present study indicated the possibility of using the transparent sheets to reduce the population density of soil-borne plant pathogen, to avoid infection within such soils in Egypt.

Under the circumstances of the current study, mulching contributed to higher soil temperature and consequently, improved growth of tomato in both seasons and enhanced the yield and its components compared with the bare soil. The results for the total yield per feddan proved that there were no significant differences between the treated root with fungicide and the three month soil solarization treatments in both seasons. The percentages increase in the estimated total yield per feddan were $21.40,18.95,12.40$ and $3.11 \%$ for treated root with fungicide, three, two and one month treatments over the control, respectively in 2014 season whereas, they were $25.65,22.51,16.40$ and $9.52 \%$ for the same treatments, respectively in 2015 season.

\section{REFERENCES}

Abou-Gharbieh, W.I, H. Saleh. And H.A. Abu-Blan 1991. Use of black plastic for soil solarization and post plant mulching. FAO Plant Production and Protection Paper 109:229-242.

Abu-Bakr, A. A. and M. M. A. El-Balla 2003. Use of plastic mulch for better performance and yield of okra during winter in Sudan. Univ. of Khartoum J. Agric. Sci. 11 (2), 214-223.

Ahmed, I.A., M.S. El-Shahaat; M.S. Nassar; K.A. Rahman and H.S. Radwan 2002. Pesticides-soil Relationships. III. Influence of three pesticides on soil stages of some nontarget insects. J. Adv. Agric. Res., 7: 885-893.

Bawazir, A.A. and A.A. Aidaros 2005. Effect of soil solarization on weeds in sesame crop in Delta Tuban, Lahej Governorate, Yemen. Arab. J. Plant Prot. 23:31-36.

Besri, M. 1982. Solar heating (solarizatlon) of tomato supports for control of Didymella lycopersic stem canker. (Abstr.). Phytopathology, 72: 928-939.

Chellemi, D. 2006. Effect of urban plant debris and soil management practices on plant parasitic nematodes, Phytophthora blight and Pythium root rot of bell pepper. Crop Protection 25:1109-1116.

Cohort, Software Inc. 2005. CoStat Users Manual, version 6.311 Berkelely, California, USA.
Dabaj, K.H., A.A. Kafu; A. Al-Khraz and M.A. Mesbah 2005. Effect of soil solarization on growth and production of cucumber Cucumis sativas L. and muskmelon Cucumis melo L. under greenhouse conditions. Arab J. Pl. Prot. 23:24-30.

Dalorima, L.T, A. Bunu, Z. Kyari, and T. Mohammed 2014. Effects of different mulching materials on the growth performance of Okra in Maiduguri. Int. Res. J. Agric. Sci. Soil Sci. 4(8):145-149.

DeVay, J.E. 1991. Use of soil solarization for control of fungal and bacterial plant pathogens including biocontrol pp 79-87. In Soil Solarization; FAO plant production and protection paper $109.369 \mathrm{pp}$.

Elmore, C.L., J. J. Stapleton, C. E. Bell and J. E. Devay 1997. "Soil Solarization" A Non-Pesticidal Method for Controlling Diseases, Nematodes, and Weeds. University of California Division of Agriculture and Natural Resources Publication, 21377.

El-Shahaat, M.S.; E.H. Eshra and Y.A. Bakr 2005. Impact of basamide and methomyl bait on non-target pests and some microbiological processes in soil. The $3^{\text {rd }}$ Inter. Conf. of Plant Protection Res. Institute, 26-29 Nov., Published in Egypt. J. Agric. Res. 83: 1007-1016.

Gamliel, A., and J. Katan 2012. Soil Solarization: "Theory and Practice". American Phytopathological Society, St. Paul.

Grossman, D.F. 1967. Selective isolation of soil microorganisms by means of differential media pp. 19-21. Sourcebook of Laboratory Exercises in Plant Pathology. American Phytopathological Society. San Francisco and London.

Hasing, J. E. 2002. Agroeconomic Effect of Soil Solarization on Fall-Planted Lettuce. Master of Science, Department of Horticulture, Faculty of the Louisiana State University and Agricultural and Mechanical College,

Hill, D.E.; L. Hankin and G.R. Stephen. 1982. Mulches and their effect on fruit set, timing and yield of vegetables. The Connecticut Agric. Exp. Stat., 805.15 pp.

Katan, J. 1985. Solar Disinfestations of soils, Proc. $4^{\text {th }}$ Inter. Congress of Plant Pathol. P.274. Parker, C.A., A.D. Rovera, K.J. Moore, and P.T.W. Wong, Eds. The Amer Phytopathol. Soc., St., Paul.

Katan, J. and J.E DeVay. 1991. Soil Solarization: Historical perspectives principals and uses. Pp. 13 - 38 in Katan, J. and J.E. DeVay, Eds. Soil Solarization, CRC Press, Boca Raton.

Krueger, R., and R. McSorley 2009 Solarization for Pest Management in Florida. Institution of Food and Agricultural Sciences Extension:1-8.

Mahrer, Y., and E. Shilo 2012. Physical Principles of Solar Heating of Soils, Soil solarization: Theory and Practice, American Phytopathological Society, St. Paul. pp. 147152. 
Mansoori, B. and N.K.H. Jaliani 1996. Control of soilborne pathogens of watermelon by solar heating. Crop Prot 15:423-424. doi:10.1016/0261-2194 (95) 00148-4.

Marquez, J. and K. Wang 2014. Soil solarization as an organic pre-emergent weed management tool on $\mathrm{O}^{\prime}$ ahu. Hānai'Ai/The Food Provider, March-May, 2014,1-6.

Mashingaidze, A.B. and O.A. Chivinge 1998. Mechanical and physical weed control; Chapter 3. In Weed Ecology and Management (eds): Nectar natura module for the Msc in sustainable crop protection.

McGovern, R.J.; R. Mc Sorley and R.R. Urs 2000. Reduction of Phytophthora blight of Madagascar periwinkle in Florida by soil solarization in autumn. Plant Dis 84:185191. doi:10.1094/PDIS.2000.84.2.185.

McSorley, R. and H.K. Gill. 2013. Introduction to soil solarization. ENY-062. Entomology and Nematology Department, Florida Cooperative Extension Service, IFAS, University of Florida, Gainesville, FL.

Minuto, A.; Q. Migheli and A. Garibaldi 1995. Integrated control of soil-borne plant pathogens by solar heating and antagonistic microorganisms. Act Hort (ISHS) 238: 138144.

Minuto, A.; D. Spadaro; A. Garibaldi and M.L. Gullino 2006. Control of soilborn pathogens of tomato using a commercial formulation of Streptomyces griseoviridis and solarization. Crop Prot. 25: 468-475. doi:10.1016/ j.cropro.2005.080001.

Morgan, D.P.; J.A. Liebman; L. Epstein and M.J. Pimenez 1991. Solarizing soil planted with cherry tomatoes vs. solarizing fallow ground for control of Virticillium wilt. Plant Dis. 75: 148-151.

Moura, M.L.R. and J. Palminha 1994. A non chemical method for the control of Pyrenochaeta lycopersici of tomato in the north of Portugal. Acta Hort. (ISHS) 366: 317-322.

Polizzi, G.; R. La Rosa; C. Arcidiacono and A. D'Emilio 2003. Effect of innovative films in soil solarization for the control of soil-borne pathogens. Acta Hort (ISHS) 614: 805-811.

Pullman, G.S. and J.E. DeVay. 1984. Soil solarization: A nonchemical method for controlling disease and pests. Cooperative Extension Davis, University of Calltornia Division of Agriculture and Natural Resources, Leaflet 21377.

Pullman, G.S.; J.E DeVay; R.H. Garber and A.R. Weinhold. 1981. Soil solarizatlon: effects on Verticilil wilt of cotton and soil-borne populations of Verticillium dahhae, Phythium spp, Rhizoctonia solani and Thielaviopsis basicala. Phytopathology, 71: 954-959.

Rajablariani, H. R., F. Hassankhan, and R. Rafezi 2012. Effect of colored plastic mulches on yield of tomato and weed biomass. Intern. J. of Environ. Sci. and Develop., 3 (6): 590-593.
Rodriguez Perez A.; S. Diaz Hernandez and L. Gallo Llobet 2004. Eradication of Phytophthora nicotianae and Rhizoctonia solani by double layer solarization in tomato seedbeds. Acta Hort (ISHS) 698: 207-211.

Salman, S.R., M.O. Bakry,. A.F. Abou-Hadid and A.S. ElBeltagy 1991. The effect of plastic mulch on the microclimate of plastic house. Acta Horti. 287: 217-425.

Sarhan, A.R.T. 1991. Control of Fusarium solani in broad by solar heating of the soil heating in North Iraq.; FAO plant Production and protection paper, 109:108-117.

Satour, M.M. 1997. Prospects of implementation of soil solarization in Egypt. 14 ${ }^{\text {th }}$ Int. Congr. for Plastic in Agric. Tel-Aviv, Israel. March 9-14, 1997.

Satour, M.M.; E. Sam; M. EI-Sherif; L. EI-Ghareeb; S.A. EIHaddad and H.R. EI-Wakil. 1991. Achievement of soil solarization in Egypt. FAO plant Production and protection Paper, 109: 200-211.

Schneider, P.M. 1979. Comportamento e propriedades térmicas do solo Santa Maria. Piracicaba, 77p. Dissertação (Mestrado) Escola Superior de Agricultura "Luiz de Queiróz"/Universidade de São Paulo.

Snedecor G.W. and W.G. Cochran 1994. Statistical Methods. $8^{\text {th }}$ Ed. USA: Iowa State University Press. Pp. 834.

Soliman, M. A., Hala A. Abd El-Aal, R. A. Mohmed and N. N. Elhefnawy 2015. Growth, fruit yield and quality of three strawberry cultivars as affected by mulch type and low tunnel. J. Alex. Sci. Exch., 36 (4): 402-414.

Standifer, L.C.; P.V. Wilson and R. Proche-Sorbet 1984. Effects of solarization on soil weed populations. Weed Sci., 32: 569-573.

Stapleton, J.J. 1991. Soil solarization in tropical agriculture for pre-and post-plant applications. FAO plant production and protection paper, 109:220-224.

Stapleton, J.J. 2000. Soil solarization in various agricultural production systems. Crop Protection 19: 837-841.

Stapleton, J.J. 2008. UC State wide IPM Program, Kearney Agricultural Center, Parlier, CA. Soil Solarization Informational Web site. Accessed Sept. 11, 2008.

Stapleton, J.J. and J.E. DeVay 1984. Thermal components of soil solarization as related to changes in soil coot microflora and increased plant growth response. Phytopathology, 7: 255-259.

Stapleton, J.J. and J.E. DeVay 1986. Soil solarization: A non chemical approach for management of plant pathogens and pests. Crop Protection, 5:190-199.

Streck, N.A., F.M. Schneider, G.A. Buriol and A.B. Heldwein 1995. Effect of polyethylene mulches on soil temperature and tomato yield in plastic greenhouse. Sci. Agric., Piracicaba, Braz., 52 (3): 587-593.

Zen-El-Dein, Manal, M.S. and T.R. Yakout 2013. Soil solarization as an environmental friend method for controlling soil-borne fungi infesting tomato plants. Pakistan J. Biolo. Sci., 16:112 -119, 2013. 


\section{الملغص العرب}

\section{تأثير التقيم اللثطي عل أمرالن فلربك التربة المؤثرة عل نمو ولنتاج المالملم المنزرعةهي التربة

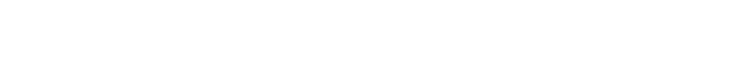

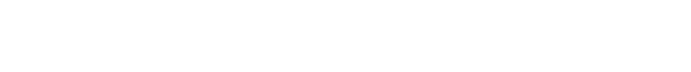

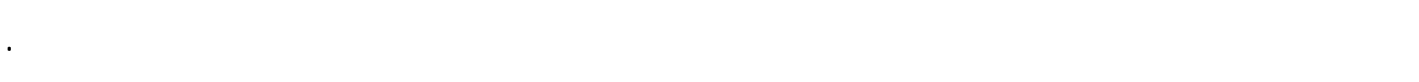

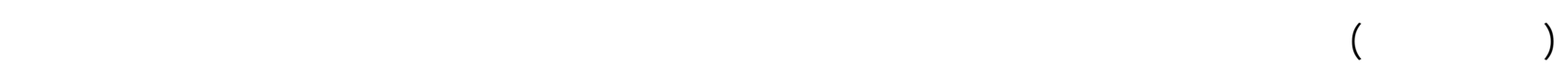

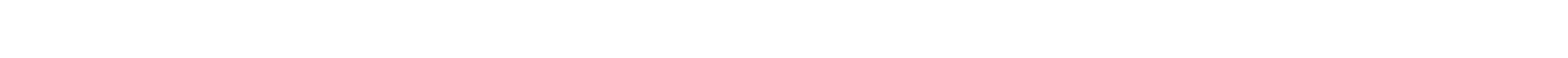

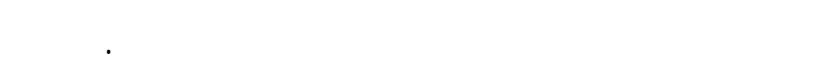

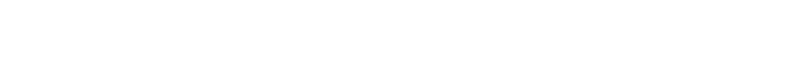
بحوث الصبحيه معرد بحوث البساتين، محلظة الإسكندرية،

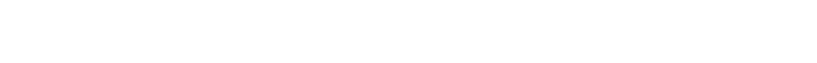
سطح التربة بالبلمستيك الثفف المدة ثلاثة أشهرر في كلا الموسمن. حيث كلت نسبة الزياة المئوية في العائد

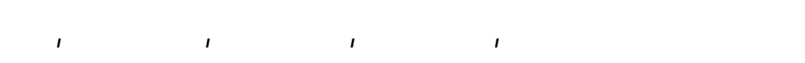

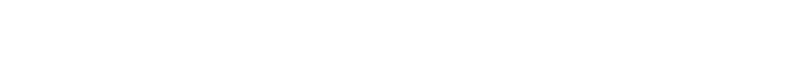

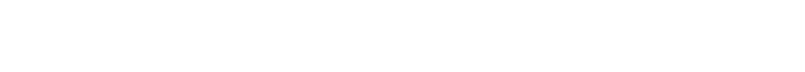

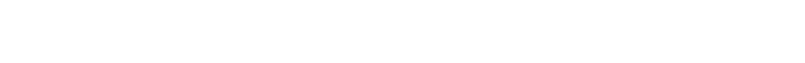
حين كلت عالت ro,70،

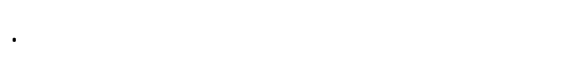

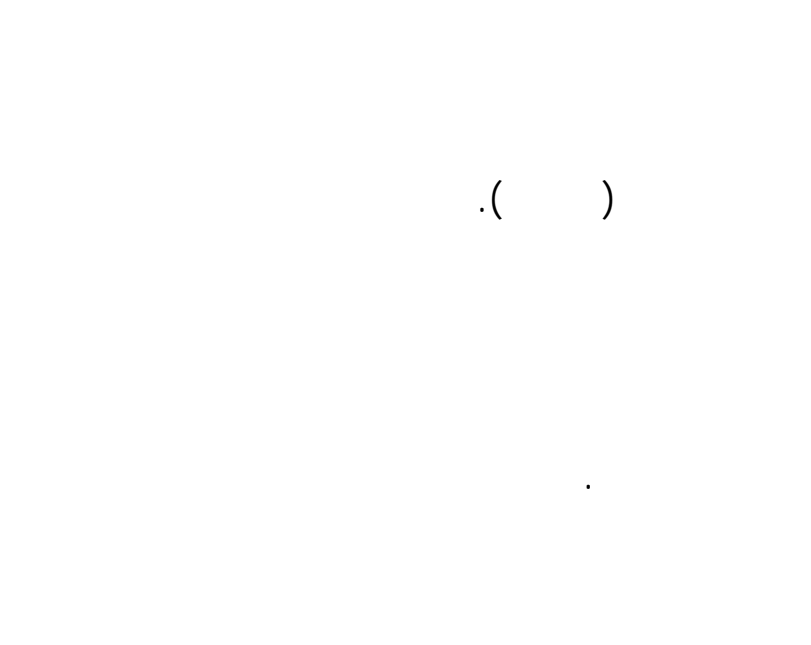

